\title{
STREPTOCOCCAL ALLERGY IN ACUTE RHEUMATIC INFECTION.
}

BY

\author{
RONALD A. MACDONALD, M.B., Ch.B., D.P.H.
}

Assistant Pathologist and Research Fellow (The Ida Sebag-Montefiore Research Fellowship), Hospital for Sick Children, Great Ormond St., London.

The ætiology of rheumatism has engaged the attention of bacteriologists for many years, and yet it is impossible to say that any definite conclusion has been reached. Many authors have suggested various types of non-hæmolytic streptococci as possible causes, but none of their claims has been definitely established, and the vast amount of literature that has accumulated does not bring us much nearer a solution to the problem. It is our intention to review a small portion of this literature, adding the results of certain investigations of our own, and to endeavour to explain some of the anomalous findings, on the supposition that there is no one definite streptococcus that is the cause of rheumatism, but that the disease is a manifestation of hypersensitiveness (allergy or hyperergy) to streptococci in general, and that in suitable circumstances any streptococcus may become the infecting agent provided the necessary degree of hyper-sensitiveness has been attained.

We propose first to examine some of the sources from which microorganisms have been obtained, and the bacteriological findings in each case ; then to discuss the question of allergy, and some of the experimental work that has been done on it; and finally to apply this theory to rheumatism, using it to explain some of the bacteriological difficulties in the disease.

\section{Bacteriological investigations.}

(a) Tonsils.-Attention has been directed consistently and for many years to the tonsil as a focus of infection, and any authors who have described 'rheumatic streptococci' have always been able to isolate them from the tonsil. On this account an investigation was undertaken in the hospital to see if there were any cultural differences in their streptococcal flora between rheumatic and non-rheumatic tonsils.

The tonsils selectcd were removed in the casualty department, and sent up to the laboratory with the minimum of delay. The rheumatic series was taken from all types of rheumatism, including chorca and old-standing carditis, the control series being from cases from which no history of rheumatism could be elicited. Immediately on receipt the tonsils were washed twice in sterile normal saline and dissected, and swabs taken from the bottom of the crypts. The swabs were then placed in tubes of broth $(2 \mathrm{c.cm}$.) and thoroughly rinsed out. One or two loopfuls, according to the turbidity of the resulting emulsicn, were spread out on chocolate agar plates and incubated for 48 hours. For the first half of the series 5 per cent. boiled bloodagar was used, but later Crowe's ${ }^{1}$ medium was adopted. This medium is ideal for differentiating streptococcal colonies, as it shows morphology and peroxide formation better than any other. 
After incubation a general survey of the relative numbers of colonies on the plate was made, and then a single colony of each streptocococcus was picked off under a binocular dissecting microscope $(\times 10)$, and its appearances noted. The colonies were placed in tubes of heart-digest broth and incubated for 24 hours. With the resulting growths the following tests were carried out :-naked eye appearance of the growth in broth, morphology in liquid and solid media, growth at $20^{\circ} \mathrm{C}$. in lactose gelatin, sugar fermentation (saccharose, lactose, raffinoss, inulin, salicin, mannite and the effect on milk), heat resistance $\left(5,10,20,30\right.$ minutes at $60^{\circ} \mathrm{C}$.), hæmolysis and bile solubility. Each organism was subcultured on Crowe's medium to determine if it were pure, or if its appearance had altered on subculture ; the appearances of the colonies were described minutely after 2 and 5 days' incubation. Hæmolysis was tested for by adding 10 drops of the 24 hour broth culture to 10 drops of a 5 per cent. suspension of washed red blood corpuscles in normal saline in a Wassermann tube, incubating for 2 hours, and leaving overnight in the ice chest. By this means the amount of hæmolysis could be noted in the same way as in the Wassermann reaction, reading $4,3,2,1,0$, according to the amount of cellular deposit, and the colour of the supernatant fluid. This method was found to be very accurate and, as little difference was seen between cultures and centrifuged supernatant fluids, also very rapid, since the same broth culture could be used as for the sugars. "Human corpuscles were employed for the most part, as a parallel series showed them to be rather more sensitive to hæmolysis than sheep's corpuscles, though less susceptible to darkening or mothæmoglobin production.

The complete results of all the tests are given in Table 1 .

The most striking thing in this comparative series (Table 1) is the extraordinarily similarity between the rheumatic and the control figures. In no single particular, except perhaps the number of streptococci isolated per tonsil, is there any material difference. Nor indeed was there, as a rule, any marked difference between the appearance of a plate from a rheumatic and a non-rheumatic tonsil, looked at generally ; and even on Crowe's medium it was impossible to tell if any given plate was from arheumatic or a control tonsil. In some cases practically pure growths resulted from both types of tonsil, but these were quite indiscriminate and might in either series be green, nongreen, or hæmolytic. Most observers who have described rheumatic streptococci have placed them in the non-hæmolytic and non-grsen-producing group, and therefore in a series of.this nature we might reasonably expect to find this group preponderating in the rheumatic series. Once again, however, there is little difference, the rheumatic being slightly lower. This accords well with the work of Hitchcock ${ }^{2}$, who found no greater incidence of inert streptococci in rheumatic fever throats than in others.

(b) Teeth, nasopharynx, etc-With regard to the mouth, teeth and nasopharynx, not nearly so much work has been done, but at the same time some authors believe that they play as important a part as foci of infection as do the tonsils. Rolleston in 1910 said that he considered patients with oral sepsis specially prone to relapses of rheumatic fever, and Langmead ${ }^{3}$ (1920) mentions throat, nose, mouth, nasopharynx and bowel as possible sources of infection. Shaw ${ }^{4}$ in 1925 showed a parallel between the incidence of diseases of the mouth, testh, gums and fæces, as apart from tonsillitis, and that of rheumatic fever. Fordyce ${ }^{5}$ (1927) agrees with Langmead in suggesting the treatment of carious teeth, adenoids and constipation, as well as tonsils, with a view to removing focal infection.

(c) Frces.-Langmead and Fordyce both mention the bowel, and other suggestions have been put forward with regard to the part it plays in rheumatism. There is very little literature dealing with the bacterial flora of the 
TABLE 1

Comparative series of rhelatatic and control tonsils

\begin{tabular}{|c|c|c|c|c|c|c|c|c|c|}
\hline & & & & & & & & Rheumatic & Non-rheumatic \\
\hline Total no. of $t$ & onsils & $\ldots$ & $\ldots$ & $\ldots$ & $\cdots$ & . & . & 50 & 48 \\
\hline Total no. of $\mathrm{s}$ & treptococci & . & . & .. & . & . & .. & 190 & 150 \\
\hline Average no. 0 & ff varieties o & f strepto & ococ & per tor & nsil & . & . & $3 \cdot 8$ & $3 \cdot 3$ \\
\hline Types & $\left\{\begin{array}{l}\text { Hæmolytic } \\
\text { Non-hæmo } \\
\text { Green prod } \\
\text { Non-green } \\
\text { Doubtful }\end{array}\right.$ & $\begin{array}{l}\text { ducers } \\
\text { or inert } \\
\text {. }\end{array}$ & $\begin{array}{l}\cdots \\
\cdots \\
\cdots \\
\ldots\end{array}$ & $\begin{array}{l}\cdots \\
\cdots \\
\cdots \\
\cdots \\
\cdots\end{array}$ & $\begin{array}{l}\cdots \\
\cdots \\
\cdots \\
\cdots \\
\cdots\end{array}$ & $\begin{array}{l}\cdots \\
\cdots \\
\cdots \\
\cdots \\
\cdots\end{array}$ & $\begin{array}{l}\cdots \\
\cdots \\
\cdots \\
\cdots \\
\cdots\end{array}$ & $\begin{array}{r}14 \% \\
86 \% \\
46 \% \\
51 \% \\
3 \%\end{array}$ & $\begin{array}{r}14 \% \\
86 \% \\
46 \% \\
53 \% \\
1 \%\end{array}$ \\
\hline $\begin{array}{l}\text { By sugar } \\
\text { reactions }\end{array}$ & $\left\{\begin{array}{c}\text { Str. mitis } \\
, " \text { salivar } \\
, \text { pyoger } \\
, \text { fæcalis } \\
\text { Other stre }\end{array}\right.$ & $\begin{array}{l}\text { rius } \\
\text { nes } \\
\text { ptococci }\end{array}$ & $\begin{array}{l}\cdots \\
\cdots \\
\cdots \\
i\end{array}$ & $\begin{array}{l}\cdots \\
\cdots \\
\cdots \\
\cdots \\
\cdots\end{array}$ & $\begin{array}{l}\cdots \\
\cdots \\
\cdots \\
\cdots \\
\cdots\end{array}$ & $\begin{array}{l}\cdots \\
\cdots \\
\cdots \\
\cdots \\
\cdots\end{array}$ & $\begin{array}{l}\cdots \\
\cdots \\
\cdots \\
\cdots \\
\cdots\end{array}$ & $\begin{array}{c}44 \% \\
26 \% \\
12 \cdot 5 \% \\
4 \% \\
13 \cdot 5 \%\end{array}$ & $\begin{array}{l}37 \% \\
28 \% \\
11 \cdot 5 \% \\
3 \% \\
20 \cdot 5 \%\end{array}$ \\
\hline $\begin{array}{l}\text { By Crowe's } \\
\text { colour } \\
\text { grouping }\end{array}$ & $\left\{\begin{array}{cc}\text { Grp. A. } \\
, \text { B. } \\
\Rightarrow \text { C. } \\
\Rightarrow \text { D. I } \\
\text { Hæmolytic }\end{array}\right.$ & $\begin{array}{l}\text { No color } \\
\text { Yellow . } \\
\text { Green } \\
\text { Black }\end{array}$ & $\begin{array}{l}\text { ur } \\
\cdots \\
\cdots\end{array}$ & $\begin{array}{l}\cdots \\
\cdots \\
\cdots \\
\cdots\end{array}$ & $\begin{array}{l}\cdots \\
\cdots \\
\cdots \\
\cdots \\
\cdots\end{array}$ & $\begin{array}{l}\cdots \\
\cdots \\
\cdots \\
\cdots \\
\cdots\end{array}$ & $\begin{array}{l}\cdots \\
\cdots \\
\cdots \\
\cdots \\
\cdots\end{array}$ & $\begin{array}{r}26 \% \\
27 \% \\
32 \% \\
1 \% \\
14 \%\end{array}$ & $\begin{array}{c}23 \cdot 75 \% \\
28 \cdot 75 \% \\
28 \cdot 75 \% \\
2 \cdot 5 \% \\
16 \cdot 25 \%\end{array}$ \\
\hline $\begin{array}{l}\text { Growth in } \\
\text { broth }\end{array}$ & $\left\{\begin{array}{l}\text { Clear } \\
\text { Turbid } \\
\text { Doubtful }\end{array}\right.$ & $\begin{array}{l}\cdots \\
\cdots \\
\cdots\end{array}$ & $\begin{array}{l}\cdots \\
\cdots \\
\cdots\end{array}$ & $\begin{array}{l}\cdots \\
\cdots \\
\cdots\end{array}$ & $\begin{array}{l}\cdots \\
\cdots \\
\cdots\end{array}$ & $\begin{array}{l}\cdots \\
\cdots \\
\cdots\end{array}$ & $\begin{array}{l}\cdots \\
\cdots \\
\cdots\end{array}$ & $\begin{array}{r}42 \% \\
56 \% \\
2 \%\end{array}$ & $\begin{array}{c}42 \cdot 5 \% \\
56 \cdot 5 \% \\
1 \%\end{array}$ \\
\hline $\begin{array}{c}\text { Chain } \\
\text { formation }\end{array}$ & $\left\{\begin{array}{l}\text { Medium an } \\
\text { Short chain }\end{array}\right.$ & $\begin{array}{l}\text { ad long c } \\
\text { ns, pairs }\end{array}$ & $\begin{array}{l}\text { chai } \\
\text { s anc }\end{array}$ & $\begin{array}{l}\text { s... } \\
\text { clumps }\end{array}$ & $\begin{array}{l}\cdots \\
\cdots\end{array}$ & $\begin{array}{l}\cdots \\
\cdots\end{array}$ & $\begin{array}{l}\cdots \\
\cdots\end{array}$ & $\begin{array}{l}37 \% \\
63 \%\end{array}$ & $\begin{array}{l}41 \% \\
59 \%\end{array}$ \\
\hline
\end{tabular}

bowel in rheumatism, and therefore we have examined a small number of specimens of fæces in the same way as we did the tonsils. As before, swabs were taken from the fæces, emulsified in broth, and the emulsion plated out on Crowe's plates. Similar reactions were carried out with pure growths of the resulting colonies. In this series the cases were all in hospital, and were mostly acute joint or cardiac conditions, with one or two cares of chorea.

The first point to be noted in this series is that there are definitely more varieties of streptococci in the rheumatic specimens than in the nonrheumatic. This is confirmed by looking at the plates, which show in general more numerous colonies of streptococci in the rheumatic series. The next point is the increase of green varieties in the rheumatics, and at the same time the reduction in the heat-resisters. This rather suggests that more of the mouth types were present in the rheumatic bowel. One striking point is evident in both series, namely, the small proportion of true fæcalis types, as judged by 
TABLE 2

Comparative SERIES OF RHEUMatic AND CONTROL FAeES

\begin{tabular}{|c|c|c|c|c|c|c|c|c|c|}
\hline & & & & & & & & Rheumatic & Non-rheumatic \\
\hline Number of $\mathrm{s}]$ & ecimens & $\cdots$ & . & . & . & . & . & 14 & 14 \\
\hline Number of st & eptococci & olated & . & $\cdots$ & . & . & . & 61 & 46 \\
\hline Average no. & f strep. $p$ & specime & & . & $\cdots$ & $\cdots$ & $\cdots$ & $4 \cdot 4$ & $3 \cdot 2$ \\
\hline Types & $\left\{\begin{array}{l}\text { Hæmoly } \\
\text { Green-p } \\
\text { Non-gre }\end{array}\right.$ & produc & $\ddot{*}$ & $\begin{array}{l}\cdots \\
\cdots \\
\cdots\end{array}$ & $\begin{array}{l}\ldots \\
\cdots \\
\ldots\end{array}$ & $\begin{array}{l}\cdots \\
\cdots \\
\cdots\end{array}$ & $\begin{array}{l}\ldots \\
\cdots \\
\cdots\end{array}$ & $\begin{array}{l}- \\
51 \% \\
49 \%\end{array}$ & $\begin{array}{l}- \\
-36 \cdot 5 \% \\
63 \cdot 5 \%\end{array}$ \\
\hline $\begin{array}{l}\text { By Crowe's } \\
\text { colour } \\
\text { gruuping } \\
\text { Mannite fern } \\
\text { True fæcalis }\end{array}$ & $\begin{array}{l}\text { A. } \\
\text { B. } \\
\text { C. } \\
\text { D. } \\
\text { enters } \\
\text { ypes }\end{array}$ & $\begin{array}{l}\ldots \\
\ldots \\
\ldots \\
\ldots \\
\ldots \\
\ldots\end{array}$ & $\begin{array}{l}\cdots \\
\cdots \\
\cdots \\
\cdots \\
\cdots \\
\cdots\end{array}$ & $\begin{array}{l}\cdots \\
\cdots \\
\cdots \\
\cdots \\
\cdots \\
\cdots\end{array}$ & $\begin{array}{l}\cdots \\
\cdots \\
\cdots \\
\cdots \\
\cdots\end{array}$ & $\begin{array}{l}\cdots \\
\cdots \\
\cdots \\
\cdots \\
\cdots\end{array}$ & $\begin{array}{l}\ldots \\
\ldots \\
\cdots \\
\cdots \\
\ldots \\
\ldots\end{array}$ & $\begin{array}{r}47 \cdot 5 \% \\
9 \cdot 0 \% \\
42 \cdot 0 \% \\
1.5 \% \\
26 \cdot 5 \% \\
13.0 \%\end{array}$ & $\begin{array}{c}61 \cdot 5 \% \\
8 \cdot 0 \% \\
28 \cdot 5 \% \\
2 \cdot 0 \% \\
28 \% \\
15 \cdot 0 \%\end{array}$ \\
\hline $\begin{array}{c}\text { Heat } \\
\text { resistant } \\
\text { types }\end{array}$ & $\begin{array}{l}5 \text { min. } \\
15 \text { min. } \\
30 \text { min. } \\
\text { Non-res }\end{array}$ & $\begin{array}{l}60^{\circ} \mathrm{C} . \\
60^{\circ} \mathrm{C} . \\
60^{\circ} \mathrm{C} . \\
\text { ant }\end{array}$ & $\begin{array}{l}\cdots \\
\cdots \\
\cdots \\
\ldots\end{array}$ & $\begin{array}{l}\cdots \\
\ldots \\
\ldots \\
\ldots\end{array}$ & $\begin{array}{l}\cdots \\
\cdots \\
\cdots \\
\ldots\end{array}$ & $\begin{array}{l}\cdots \\
\cdots \\
\cdots \\
\cdots\end{array}$ & $\begin{array}{l}\cdots \\
\cdots \\
\cdots \\
\ldots\end{array}$ & $\begin{array}{r}15.0 \% \\
5.0 \% \\
15.0 \% \\
65.0 \%\end{array}$ & $\begin{array}{r}13.0 \% \\
4.0 \% \\
28.0 \% \\
55.0 \%\end{array}$ \\
\hline $\begin{array}{l}\text { By sugar } \\
\text { reactions }\end{array}$ & $\left\{\begin{array}{l}\text { Fæcalis } \\
\text { Mitis gr } \\
\text { Salivari } \\
\text { Others }\end{array}\right.$ & $\begin{array}{l}\text { oup } \\
\text { p.. } \\
\text { group } \\
\text {.. }\end{array}$ & $\begin{array}{l}\cdots \\
\cdots \\
\cdots \\
\ldots\end{array}$ & $\begin{array}{l}\cdots \\
\cdots \\
\cdots \\
\ldots\end{array}$ & $\begin{array}{l}\cdots \\
\cdots \\
\cdots \\
\ldots\end{array}$ & $\begin{array}{l}\cdots \\
\cdots \\
\cdots \\
\cdots\end{array}$ & $\begin{array}{l}\cdots \\
\cdots \\
\cdots \\
\ldots\end{array}$ & $\begin{array}{c}26 \cdot 5 \% \\
61 \cdot 0 \% \\
5 \cdot 5 \% \\
7 \cdot 0 \%\end{array}$ & $\begin{array}{c}28 \cdot 0 \% \\
57 \cdot 0 \% \\
15 \cdot 0 \% \\
-\end{array}$ \\
\hline
\end{tabular}

the classical features of morphology, heat-resistance and mannite fermentation. By far the commonest streptococcus is one of the mitis type, which is not heat-resistant.

Mention must be made at this point of the differences between solid and liquid specimens. We asked for liquid specimens to be sent, but in all cases this was not possible, and a definite difference was noted between the two. In the first place, the percentage of streptococci as compared with B. coli and other organisms was considerably lower in the solid specimens. Secondly, these contained more fæcalis types. This seems to show that the streptococcal flora of the bowel alters in accordance with the level from which the specimen comes. Naturally our series is too small to allow us to be dogmatic, but the alteration in bowel content, and the increase of streptococci in the rheumatic series, are sufficiently striking to warrant further investigation. Apart from these points there is little difference between the two series, and though the rheumatic group contained more varieties of streptococci in each specimen, no particular types preponderated, and as far as we could make out, there were no types present in the rheumatic series which were not at some time or other also isolated from the control series. 
(d) Blood and post-mortem cultures.-Blood cultures in acute rheumatism are notoriously unsatisfactory on account of their being so frequently negative, even in cases with high temperatures. Lynch $^{6}$ (1924) draws a distinction between the very small number of positives in acute rheumatism, and the large number in bacterial endocarditis. Swift and Kinsella (1917) found less than 10 per cent. positive in their series of blood cultures, and of the strains of streptococci found in these 10 per cent., none bore any relation to one another, or to any isolated elsewhere. Jones ${ }^{8}$ (1928), using a very full technique, found only one positive in 33 cultures. Our own cases accord with these findings, no positives being obtained in the last 20 cultures, except in cases of bacterial endocarditis, where green streptococci have nearly always been present.

Cultures from heart valves, myocardium and pericardial fluid have, as a rule, been more successful, and in the few cases which we have had an opportunity of culturing, streptococci have nearly always been isolated. The possibility of contamination must not, however, be overlooked in interpreting these findings, as streptococci of the fæcalis type, and even occasionally others, are sometimes present in pericardial fluid and heart blood, where their presence is entirely accidental. Recently we have been adopting the technique of flaming pieces of heart muscle or valves in spirit, and then excising, with aseptic precautions, a piece from the inside of the slightly scorched specimen. In this way we have isolated streptococci pure in two cases, one having a greenproducing short-chain streptococcus of the mitis type, and the other two nonhæmolytic ard non-green varieties. Zinsser ${ }^{9}$ (1928) mentions that he also found two distinct types of streptococcus in heart muscle from an authentic case of rheumatism, a point of definite importance when considering a specific streptococcal ætiology for the disease.

(e) Joints and nodules.-Here again attempts at isolation of organisms have been almost uniformly unsuccessful. As regards the joints, this is not surpiiving in a disease which never produces suppuration, and in which the inflammation flits about from joint to joint. In one or two cases positive findings have been reported, but the diagnosis in these cases has not been well established. Crowe ${ }^{10}$, however, has described what he has named osteotropic streptococci, which have a special affinity for bone tissuc, and on intravenous injection into rabbits will settle down under the articular surfaces of some of the larger bones. Though he is dealing with osteo-arthritis in his paper, it is possible that organisms may be localized temporarily in this position in more acute conditions, in which case the negative findings in joint fluid could be explained. We shall refer to this point again in the discussion.

\section{Skin tests.}

A considerable amount of work has been done on skin tests with nonhæmolytic streptococci, using the same technique as in the Dick test, and a fair amount of success has been met with. Birkhaug ${ }^{11}$ (1927) produced a soluble exo-toxin from his non-methæmoglobin-forming streptococcus, with which he performed a large number of skin tests, obtaining a considerably higher percentage of positives in rheumatic patients than in others. Later ${ }^{12}$ 
in 1929 he summarized the results of tests done in various parts of Europe on 594 individuals. His results were as follows :-72 per cent. positive to nonhæmolytic streptococcal products in active rheumatism, with 64 per cent. positive to boiled streptococcal filtrates. In non-active cases his figures were 64 per cent. and 25 per cent. respectively, while in non-rheumatic controls he obtained only 14 per cent. of positives. Kaiser ${ }^{13}$ (1928) using Birkhaug's original toxin at 1 in 100 strength found 32 per cent. of all children positive, 20 per cent. where there was no history of rheumatism, 35 per cent. in cases of repeated sore throat, and 72 per cent. in cases with a history of rheumatism. Swift, Wilson and Todd ${ }^{14}$ (1929) did skin tests with green and non-green streptococci, and found a greater number of positives in active than in inactive or cured cases ; that boiled filtrates were less positive in inactive cases, and that generally rheumatic patients gave more positives than others. They also found no correspondence between Dick tests, and tests with non-hæmolytic streptococci. Edith Jones ${ }^{8}$ (1928) found hyper-sensitiveness in rheumatic fever patients to a large viriety of non-hæmolytic streptococci as evidenced by positive skin reactions with filtrates of these strains. Howell and Corrigan ${ }^{15}$ (1928) obtained a relatively high percentage of positives with many types of streptococci in children, which they describe as susceptible to streptococcal infections in general.

Comparatively little work has been done in this hospital with skin tests with non-hæmolytic streptococci, but a small number of children have been tested with various strains. The numbers of positives have not varied much with the organisms employed. It would seem that there is some definite hyper-sensitiveness to streptococcal products which can be revealed by skin tests, but the difficulty at present is that the optimum method of preparing the products, and the organisms from which to derive them, have not yet been decided. Recent work tends to point to autolysis as being an important step in the preparation of a toxin, and that organisms which autolyse easily, and therefore liberate their proteins, are more potent than others, irrespective of their origin or supposed pathogenicity.

\section{Animal experiments.}

The literature on this subject is immense, as nearly every one who has worked at the bacteriology of rheumatism has tried to reproduce the clinical picture of the disease in some animal, usually the rabbit. What is more, considerable success has been met with in the experiments, some degree of arthritis, and often of the non-suppurative variety, having been produced in very many instances. Poynton ${ }^{16}$ in 1904 was able to produce arthritis and carditis in rabbits and monkeys, with cultures of his diplococcus from a fatal case of rheumatic endocarditis; and from then onwards to the present day most authors, including Beattie ${ }^{17}$ (1906), Coombs, Miller and Kettle ${ }^{18}$ (1912), Faber $^{19}$ (1915), Small ${ }^{20}$ (1927), Birkhaug ${ }^{11}$ (1927) and a host of others have repeated this with the organisms they isolated. Most of the workers used large doses which were in many cases injected intravenously, thus possibly accounting for the slight differences between the resulting pathological pictures and those of human rheumatism. 
Though this production of a fairly typical arthritis in animals would seem to fulfil one of Koch's postulates, yet by no means all the experiments were performed with the same organism, and coincidently with them arthritis was produced by streptococci which had no possible connection with rheumatism. Cole ${ }^{21}$ (1904) found lesions in rabbits injected with ordinary alimentary S. fæcalis and salivarius identical with those from 'rheumatic' streptococci. Gordon ${ }^{22}$ (1912) agrees with this, and Jackson ${ }^{23}$ (1913) found no striking differences in the reactions in rabbits to different types of streptococci, and Henrici ${ }^{24}$ (1916) endorses this view. Rothschild and Thalhimer ${ }^{25}$ produced arthritis in about 50 per cent. of their rabbits by inoculation with a considerable variety of streptococci. Topley and Weir's (1921) point out that though lesions similar to human rheumatism can be produced by inoculation with streptococci from acute rheumatic cases, similar lesions can be produced by streptococci from widely different sources.

\section{Discussion on allergy.}

(1) Introduction.--There are four main points to be observed on looking through the bacteriological findings from these various sources, and the results of skin tests and animal experiments.

(1) That the ætiology of rheumatism is intimately connected with streptococci ;

(2) That authors who have described streptococci have not been able to place them in one cultural, morphological, bio-chemical or serological group ;

(3) That positive skin tests have been obtained in cases of rheumatism with the products of many different non-hæmolytic streptococci;

(4) That unrelated streptococci, from various unconnected sources, have been as successful in producing experimental arthritis in animals as have those from cases of rheumatism.

These last three points make it very difficult to attribute rheumatism to one definite streptococcus, and yet with the exception of Achalme ${ }^{27}$ and his adherents, who describe a bacillus resembling anthrax, Clarke ${ }^{28}$ who suggests the rat flea as a possible carrier, and one or two authors who suggest filterable viruses, observers are unanimous in laying some blame on streptococci. That these organisms are normally present in all human beings naturally complicates the issue, and the ease with which many varieties of streptococci can be isolated from the tonsils, mouth, fæces, etc., makes their ætiological relationship more difficult to prove. It is to these normal harbours of streptococci that attention has mainly been directed with a view to eradicating focal infection, and the consequent absorption of toxins. In the case of the tonsil, this has been the main reason advanced by the large number of eminent authorities who recommend tonsillectomy in rheumatism. Yet, in spite of the undoubted value of this measure, there is, as our experiments show, a complete absence of any difference in the streptococcal flora of rheumatic and non-rheumatic tonsils. Again in the case of the intestine, one may find any streptococcus in the fæces of rheumatic or non-rheumatic cases, and very little difference between them, yet attention to the bowel is 
frequently advocated as a useful line of therapy in rheumatism. Vaccines also have given good results in some hands, and have been useless in others, and also in more chronic cases the removal of septic focci has been of great value in one case, and valueless in the next. How then are we to reconcile these conflicting results? It must be obvious that, if one definite streptococcus were the cause of rheumatism, these anomalies could not have ariscn, even though the classification of the non-hæmolytic streptococci is sufficiently difficult to have made it uncertain to which group the organisms isolated may belong. With modern methods, such as the use of differential media and serological tests, some similarity should have been observed between the numerous streptococci which have been found in rheumatic lesions. This has not been done, however, and recent work shows more and more varieties isolated, and these and others from non-rheumatic sources capable of giving positive skin tests and producing arthritis in animals.

Let us suppose then that all these organisms can produce racansism. If this is accepted, the multiplicity of results can be explained quite easily. It remains, then, to see how all these varieties can be related to the disease. Gordon $^{22}$ in 1912 suggested that rheumatism might be an auto-infection or auto-inoculation by streptococci of the normal alimentary canal, induced by exposure, damp or lowered resistance. This is a very general statement, but if we make it more specific by suggesting that this auto-inoculation is really the production of hyper-sensitiveness it brings this early statement into line with later work. Harrison ${ }^{29}$ (1913) came to the conclusion that there were two alternative explanations of rheumatism, either that more than one streptococcus is responsible, or that cultural and other characteristics are not sufficiently well defined to enable one to separate rheumatic from other streptococci. We have already mentioned this latter possibility, but do not consider that it is now tenable.

(2) Experimental work.-Faber ${ }^{19}$ (1915) was among the first to suggest hyper-sensitiveness. He injected joints with dead bacteria and, when the resulting inflammation had settled down, he found that a dose of organisms too small to produce any result in an untreated joint, when injected intra. venously, would produce arthritis in this joint. This question has been more fully worked out recently, both with streptococci and with other organisms. Zinsser and Grinnel ${ }^{30}$ (1927) produced a condition of allergy in guinea pigs by repeated injections of a pneumococcus autolysate; and Freiberg ${ }^{31}$ in 1929 succeeded in inducing a proliferative arthritis in rabbits by repeated injections of B. dysenteriæ Flexner, and says that he considers arthritis to be a local allergic manifestation of a generalized state of allergy to a specific bacterium or bacterial extract. With streptococci, as early as 1923 , Bristol ${ }^{32}$ discussed the hypothesis that scarlet fever is a hyper-sensitive state, and compares it closely with drug and serum allergy. Mackie and McLachlan ${ }^{33}$ (1927) produced a hyper-sensitive state in guinea pigs to scarlet fever toxin, and say that this state is not specific. Dochez and Stevens ${ }^{34}$ did the same with rabbits and erysipelas filtrates, and at one phase, could neutralize the condition with erysipelas immune serum. They also consider the rash of scarlet fever and the Dick reaction to be allergic manifestations. 
Turning to rheumatism and hyper-sensitiveness to non-hæmolytic streptococci, Birkhaug ${ }^{11}$ (1927) suggests that a toxin produced by a group of serologically unrelated streptococci may produce rheumatic fever by its prolonged fixation in the tissues. Subsequently ${ }^{35}$ (1928) he sensitized rabbits and guineapigs to toxins from various streptococci by giving repeated doses, and demonstrated the sensitiveness by positive skin tests in these animals which had failed to react before. In this paper he says that it is difficult to attribute the many variable manifestations of rheumatism to the action of a single microorganism. In $1929^{12}$ he explains his positive skin tests purely on the grounds of allergy, saying that there is a non-specific allergenic factor present in products of inert and viridans streptococci to which rheumatic patients react hyperergically. Swift, and his co-workers have done a great deal of research on this subject. Swift, Derick and Hitchcock ${ }^{36}$ (1927) produced allergic tuberculinlike reactions in patients after inoculation of killed streptococci or their products, and a slow febrile response, at its height in 20-24 hours, much later than nonspecific protein shock. Andrewes, Derick and Swift ${ }^{37}$ (1926) take this subject further ; in rabbits, they showed, with intradermal injections of green streptococci, lesions which reach their height in $\mathbf{2 4 - 4 8}$ hours, retrogress and then show a secondary reaction about 8 or 9 days later. Many streptococci, and occasionally pneumococci, produce this reaction, but not hæmolytic streptococci, staphylococci, B. coli or M. catarrhalis. This secondary reaction is not due to increased activity of the organisms, as the lesions are sterile, and dead organisms can produce it as well as living ones. A second injection within 9 weeks of the first, is not followed by this secondary reaction, and this inhibition is not specific among non-hæmolytic streptococci. These experiments are suggestive, and can hardly be explained except on a basis of allergy. Derick and Swift ${ }^{38}$ (1927) deal further with the hyper-sensitive state, mentioning that it can be increased up to a point by inoculations at 5-10 day intervals, and seems to depend on some lesion or focus in some part of the body. This may be produced experimentally by means of an infected agar tumour, (Crowe ${ }^{\mathbf{1 0}}$, 1929), which liberates continually a supply of allergizing material.

An interesting contribution to this subject was some work done by Hanger ${ }^{39}$ (1927). He tested rabbits and found that, as a rule, they reacted negatively to streptococcal antigens, as judged by skin tests. Rabbits have relatively few Gram-positive organisms in their nasopharynx, but relatively numerous Gram-negative bacilli, notably B. leptisepticum. Rabbits react, in the main, positively to filtrates from these bacilli, which emphasizes the importance of sensitizing foci in the body. Later he says that any rabbits which lack this sensitiveness to $\mathrm{B}$. leptisepticum can have it developed by infecting the skin with a virulent culture of the organism. Allergic rabbits die when 1 c.cm., or even less, of filtrate is given intravenously, while non-allergic rabbits will resist $15 \mathrm{c.cm}$, and immune rabbits even more. He also says that these reactions are non-specific. Swift, Derick and Hitchcock ${ }^{40}$ (1928) have obtained identical results with streptococci, being able to produce hyper-sensitiveness and immunity in the rabbit by varying their doses of non-hæmolytic streptococci, and their methods of administration. In the hyper-sensitive rabbit, a moderate dose of 
organisms produces death, or very severe lesions; in the normal rabbit a relatively slight lesion ; and in the immune rabbit no effect.

(3) Definitions of allergy.-We have described above some of the recent experimental work on allergy. Let us now try to show exactly what allergy is. Swift and Derick ${ }^{41}$ (1927) give an account of the condition as follows. :-

Hyperergy to non-hæmolytic streptococci is an early stage of resistance in which there is a maximal response of the tissues to a minimal stimulus. It is the result of the action of the antigen-the streptococci-in a limited area represented by the focus, wlere tissue destruction occurs. It may indeed depend upon substances arising in such a focus. Complete or efficient immunity, on the other hand, is an optimal response to a maximalwithin certain limits-stimulus, and is the result of the action of the antigen over a wide area without the induction of focal tissue destruction.

Zinsser $^{9}$ (1928) says much the same thing in describing allergy as

an increased capacity of the tissues to react to an antigen which may come to the body as a new infection, or through the lighting up of an old focus. This increased capacity to react may be injurious, and result in pathological changes and disease. On the other hand, in its deeper pathological significance, it probably means merely that the tissues, through specific sensitization, are on a hair trigger and can respond both cellularly and humorally to this antigen with a speed and vigour not possessed by the normal body. In this sense the allergic state may in certain instances be regarded as an index of resistance, a thing which we believe to be true in the case of tuberculosis. It is probable that, in order to produce any sort of noticeably acute pathological change in the tissues of a sensitive animal, it is necessary that the antigen shall reach the tissues in a relatively concentrated state. This seems indicated by our own experience in obtaining violent hæmorrhagic skin reactions with pneumococcus autolysate in guinea pigs, which reacted hardly at all when the same and larger amounts of antigen were distributed over the entire peritoneum by intra-peritoneal injection. It may also be that the situation is complicated by local degrees of sensitiveness of individual tissues-a view which experiments in rheumatism encourage.

(4) Application of the theory of allergy to the bacteriological problems of rheumatism.-Finally, let us link up these suggestions with the bacteriological findings described in the earlier part of this paper, and try to explain some of the anomalous facts in this way. In the first place, the lack of cultural and serological uniformity among the streptococci isolated from cases of rheumatism is easily explained. Most of the authors whom we have quoted in this discussion emphatically state that the hyper-sensitiveness that they have found or produced is not specific, and that any non-hæmolytic streptococcus, whether recognized as pathogenic or not, may, in suitable circumstances, induce the allergy; also that one streptococcus may be used to produce this state, and another to demonstrate its presence by means of skin reactions. Why then have some experiments with non-hæmolytic streptococci failed to produce an allergy, or give positive skin tests in hyper-sensitive patients? An explanation for this has been suggested in the fact that autolysis of the streptococci is the important factor in yielding allergizing material, and certainly autolysates of streptococci have been more potent than mere filtrates. It has also been suggested that some streptococci, including Birkhaug's RF1 strain, autolyse more readily than do others, and are therefore more potent. This autolysis naturally would go on more rapidly in a focus of infection where organisms are continually being destroyed by the body, than in a culture where they are living in their optimum conditions, and therefore natural autolysis and consequent liberation of allergizing material is more potent than the inoculation of cultures in experi- 
mental animals, except perhaps in the case of the infected agar tumour method. It is not presumed for a moment that this is the whole story, for when dealing with antigens we are trying to reproduce a single condition with a very complex organic substance, and we have yet to learn what fraction of the bacterial protoplasm is responsible for what effect. Thus it is probable that the experimental success of some workers with the organisms they isolated may be due to their having found organisms which autolyse easily, or that they have accidentally included the correct antigenic fraction, and not to any specific xtiological rôle in respect of those organisms.

Septic tonsils, and even indeed normal tonsils to a less extent, form very good foci from which a supply of this allergizing material can be liberated, which explains the undoubted value of tonsillectomy in rheumatism. In the same way foci of infection in other situations, such as the mouth, teeth, bowel, etc., probably liberate this allergizing material, and attention to these situations should be, as indeed it is, a useful therapeutic step. This conception is not very far removed from the older one, namely, that removal of these foci exercised its beneficial effect by removing sources from which organisms and their toxins might be diffused through the body. Probably organisms, and at any rate toxins, are occasionally disseminated through the tissues, but more important is the diffusion of allergizing material.

Inflammation of the joints, which is one of the chief manifestations of rheumatism, is somewhat analogous to serum sickness, an established allergic condition. If, then, we explain rheumatism on a basis of allergy, the sterility of the joint fluids is not surprising. There is also, of course, as mentioned above, the possibility of organisms being present in the bone under the articular cartilages. That allergy may enter into this question also is suggested by some of Crowe's ${ }^{10}$ experiments. He kept one of his osteotropic streptococci on ice for three weeks, and on injecting it into a rabbit, found it had lost its osteotropic properties. He then infected an agar tumour in a rabbit with this organism, and injected three days later a small quantity of the organism intravenously. Seventeen days later the rabbit was killed and this organism again isolated from the bone, suggesting that the infected agar tumour, by liberating allergens, had so increased the sensitivity of the animal that the organism could again settle in the bone.

On a hypothesis of allergy can also be explained the sterility of nodules and blood. The occasional positive blood cultures, and the presence of streptococci in heart muscle, are not entirely contradictory, for in the hypersensitive child, though the disease can exist in their absence, organisms may easily escape into the circulation, and hence to the tissues. It is also possible that the cases in which blood cultures are positive may form a link between acute rheumatism and bacterial endocarditis, a condition which frequently follows on rheumatism and in which blood cultures are almost invariably positive. In these cases the generalized presence of the antigen may lead more nearly to the 'optimal' response, in place oft 'he 'maximal' response of the local presence of the antigen, and thus explain the comparatively prolonged nature of bacterial 
endocarditis. That some immunity is developed is proved by the fact that definite agglutination, often to a fairly high titre, can be demonstrated in the patient's own blood to his own organisms.

Another point which fits in with the theory of allergy is the fact that children rarely develop rheumatism before the age of four years. Vining ${ }^{12}$ (1925) describes the condition of the pre-rheumatic child, and states that rheumatism in children is preceded by a period of months or years of ill-health. It arises in the 'debilitated toxic child.' Is it not possible that this is the period in which the child is becoming sensitized to the streptococci which are normally or abnormally present in its body? Mackenzie and Hanger ${ }^{43}$ found that infants nearly all gave negative skin reactions to products of various streptococci, even though their mothers reacted strongly : a fact which suggests that the infants had not yet had time to become sensitive.

\section{Summary.}

(1) Some of the literature describing streptococci isolated from various situations in rheumatic patients is reviewed, and our own results added.

(2) A series of tonsil cultures from rheumatic and non-rheumatic cases is given, showing practically no differences between them with regard to the streptococcal flora.

(3) A similar shorter series of fæces showed a greater average number of types of streptococci per specimen, and a larger percentage of green streptococci in the rheumatic specimens. Apart from this, and a slight diminution of heatresistant types in the rheumatic series, there was little difference between them.

(4) Some of the work that has been done on allergy in rheumatism is described, and a definition of the condition is quoted from two authors.

(5) Some of the bacteriological and other anomalies of rheumatism are explained on a basis of allergy.

We would like to acknowledge our indebtedness to Dr. D. N. Nabarro, Director of the Pathological Department, for his advice and encouragement during this work, and for his kindness in correcting the proofs; to the honorary and resident staff for furnishing specimens from their wards; and to the casualty department under Mr. Crooks and afterwards Mr. Keogh, for sending tonsils removed at operation.

\section{REFERENCES.}

1. Ann. P'iclieit-Thomson Research Lab., Lond., 1927, III, 251.

2. Hitchcock, ('. H., J. Exp. Med., N.Y., 1928, XLVIII, 403.

3. Langmead, F., Lancet, Lond., 1920, i, 941.

4. Shaw, T. B., Proc. R. Soc. Med., Lond., 1924-25, XVLII, 9.

5. Fordyce, A. D., J.R. San. Inst., Lond.,1927, XLVII, 669 ; Brit. Med. J., Lond., 1927, i, 1081.

6. Lynch, R., Canad. Med. Ass. J., Montreal, 1927, XVII, 1352.

7. Swift, H. F., \& Kinsella, R. A., Arch. Int. Med., Chic., 1917, XIX, 381.

8. Jones, E. J. M. Irvine-, Ibid., 1928, XLII, 784.

9. Zinssev, H., Bull. N.Y. Acad. Med., N.Y., 1928, 1V, 351.

10. Ann. Pickett-Thomson Research Lab., Lond., 1929, IV, ii, 398.

11. Birkhang, K. E., J. Infect. Dis., Chic., 1927, XL, 549. 
12. Birkhang, K. E., Ibid., 1929, XLIV, 363.

13. Kaiser, A. D., Ibid., 1928, XLII, 25.

14. Swift, H. F., Wilson, M. G., \& Todd, E. W., Am. J. Dis. Child., Chic., 1929, XXXV11I, 98.

15. Howell, K. M., \& Corrigan, M., J. Infect. Dis., Chic., 1928, XLII, 149.

16. Poynton, F. J., Brit. Med. J., Lond., 1904, i, 1117 ; Practitioner, Lond., 1904, LXXII, 864.

17. Beattie, J. M., Lancet, Lond., 1906, ii, 871.

18. Coombs, C. F., Miller, R., \& Kettle, E. H., Lancet, Lond., 1912, ii, 1209.

19. Faber, H. K., J. Exp. Med., N.Y., 1915, XXII, 615.

20. Small, J. C., Amer. J. Med. Sci., Philad., 1927, CLXXIII, 101.

21. Cole, R. I., J. Infect. Dis., Chic., 1904, I, 714.

22. Gordon, M. H., Lancet, Lond., 1912, ii, 1394, 1539.

23. Jackson, Leila, J. Infect. Dis., Chic., 1913, XII, 364.

24. Henrici, A. T., Ibid., 1916, XIX, 572.

25. Rothschild, M. A., \& Thalhimer, W., J. Exp. Med., N.Y., 1914, XIX, 429 \& 444.

26. Topley, W. W. C., \& Weir, H. B., J. Path. \& Bact., Edinb., 1921, XXIV, 3.

27. Achalme, P., Compte. Rend. Soc. de Biol., Paris, 1891, XLIII, 651.

28. Clarke, J. Tertius, Brit. J. Child. Dis., Lond., 1929, XXVI, 99.

29. Harrison, W. S., J.R. Army Med. C., Lond., 1913, XX, 1.

30. Zinsser, H., \& Grinnell, F. B., J. Bact., Baltimore, 1927, XIV, 301.

31. Freiberg, J. A., Arch. Sury., Chic., 1921, XVIII, 645.

32. Bristol, L. O., Amer. J. Med. Sci., Philad., 1923, CLXVI, 853.

33. Mackie, T. J., \& McLachlan, D. G. S., Brit. J. Exp. Path., Lond., 1927, VIII, 129.

34. Dochez, A. R., \& Stevens, F. R., J. Exp. Med., N.Y., 1927, XLVI, 487 ; Proc. Soc. Exper. Biol. \& Med., N.Y., 1926-27, XXIV, 429.

35. Birkhang, K. E., J. Infect. Dis., Chic., 1928, XLII, 280.

36. Swift, H. F., Derick, C. L., \& Hitchcock, C. H., Proc. Soc. Exp. Biol. \& Med., N.Y., 1927-28, XXV, 312 .

37. Andrews, C. H., Derick, C. L., \& Swift, H. F., J. Exp. Med., N.Y., 1926, XLIV, 35.

38. Derick, C. L., \& Swift, H. F., Proc. Soc. Exp. Biol. \& Med., N.Y., 1927, XXV, 222.

39. Hanger, F. M., Jr., Loc. cit., $230 \& 775$.

40. Swift, H. F., Derick, C. L., \& Hitcheock, C. J., J. Am. Med. Ass., Chic., 1928, XC, 906.

41. Swift, H. F., \& Derick, C. L., Proc. Sor. E.xp. Bi.l. \& M d., N.Y., 1927, XXV, 224.

42. Vining, C. 'W., Brit. Med. J., Lond., 1925, ii, 865.

43. Mackenzie, G. M., \& Hanger, F. M., Jr., J. Immum,l., Baltimore, 1927, XIII, 41. 